\title{
Malatya Yastık Halıları
}

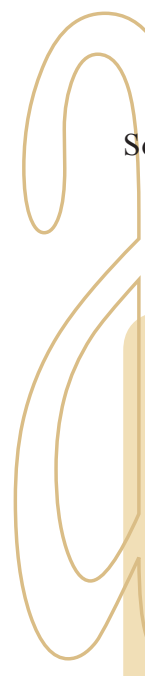

\section{ÖZET}

Araştırmanın konusunu "Malatya Yastık Halılarında Teknik Özellikler" başlığı tanımlamaktadır. Anadolu'nun her yöresinde halı; farklı kullanım amaçları ile dokunmuştur. Bu kullanım amaçları bölgenin yaşam şekli ve iklim yapısı gibi hayatla bütünlük gösteren şartlar sonucunda ortaya çımıştır. Malatya yastık halıları geçmişte karasal iklimin getirdiği zorlu kış mevsiminde dokunan ve kullanılan dokumalar olmakla birlikte günümüzde sergilik olarak tanımlanan ev döşemelerinde yoğun talep üzerine üretilmektedir. Yörede, yastık halılar için genellikle ayrı çözgüler hazırlanmakta bazen de büyük dokumalar bittikten sonra artan çözgü ipleri üzerine eklenerek dokunmaktadır. Kullanılan malzeme, dokunan motif ve oluşturulan desenler, yörenin geleneksel kültürünü yansıtan özellikler taşıması nedeniyle araştırma konusunu önemli hale getirmektedir. Malatya yastık halılarının teknik özelliklerinin belirlenmesi amacıyla araştırma konusu seçilmiştir.

Malatya il merkezindeki müze ve evlerde bulunan yastık halı örnekleri araştırma konusunun evrenini oluşturmakta, benzer özellikler gösterenler arasından seçilen dokuz adet halı yastık da alınmaktadır. Araştırma metni; kaynak taramalarından elde edilen bilgilerden alıntılar, alan araştırması ile elde edilen görsel kayıtların analizleri, dokuyucularla yapılan mülakatlardan elde edilen, değerlendirmeler ve sonuçlardan oluşmaktadır.

Anahtar Kelimeler: Malatya, Halı, Dokuma, Yastık, Halı yastık.

\section{ABSTRACT}

The subject of the study "Pillow carpets in Malatya, Technical Specifications" is defined title. Every region of Anatolia, carpet, woven with several different uses. The intended uses of the structure of the region, such as lifestyle and climate conditions is the result of a life that shows integrity, Malatya pillow woven carpets in the past continental climate brings extreme winter and Although the fabrics used today are produced on high demand sergilik defined as the home flooring.

In the region, usually a separate warp pad in preparation for carpet weaving, sometimes after a big increase on the addition of ropes woven warp.Used materials, woven patterns and designs created, reflecting the traditional culture of the region makes it an important research topic because of transport facilities Research topic was chosen in order to promote the technical features of Malatya, carpets pillow. Research the subject, in the city center of Malatya, and houses a museum showing similar features selected from among the eleven samples of carpet cushion pillow on the carpet explained and limited.Research the text, the information obtained from screening of excerpts from literature, visual records obtained by the survey analysis, interviews with dokuyucularla obtained, consists of evaluations and tests.

Key Words: Malatya, Carpet, Woven, Pillow, Carpet pillow.

* Araştırma Görevlisi, Gazi Üniversitesi M.E.F. El Sanatları Eğitimi Bölümü / ANKARA 


\section{Giris}

Geleneksel El sanatlarımız içinde yer alan el dokuması halılar, geçmişten günümüze Anadolu yaşamını, görsel anlatımındaki zengin ifade gücüyle dile getirme özelliğine sahiptir. Her bölgede farklı renk ve desen oluşumu gözlemlenen halıların bulunması bu özelliğinin belirtisidir. Doğu Anadolu Bölgesinde yer alan Malatya da, çevre illerle benzer özellik gösteren halı dokumalarıyla tanınmaktadır.

Malatya yastık halıları olarak tanımlanan araştırma konusunu, büyük boyutlu halıların, küçük ebatlı örnekleri olarak dokunan yastık halılar oluşturmaktadır. Yazılı kaynaklarda konu hakkında yeterli bilgiye ulaşılamaması konuyu önemli hale getirmektedir. Bölgede farklı desen, renk ve motif özelliği gösteren yastık halı dokumalarının teknik özelliklerinin incelenmesi amacıyla konu seçilmiştir.

Malatya halıları ilçe ve köy adları ile tanınmaktadır. Ören, Başören, Dirican, Parçikan, Kürecik halıları olarak halı pazarında adını duyurmuştur. Geçmişte günlük kullanım amacına yönelik olarak halılar dokunmuştur. İhtiyaçları karşılama amaçlı yapılan halı dokumalarda kullanılan, ipliklerinin ve boya maddelerinin doğal olması önemli özellikleri arasındadır. Dokumalardaki saçak boylarının normalden uzun ve saç örgülü olması, hav boylarının yüksekliği ve geniş bordürleri dikkat çekici diğer özellikleri arasında yer almaktadır. Malatya halıları, bu özelliklerini tamamen koruyamasa da günümüzde, kamu ve özel ortaklı halk eğitim merkezi kurslarında dokunmaktadır. Halı ürünlere; yan halısı, halı yastık, yayma (yer)halısı, divan halısı, namazlık, heybe gibi çeşitleriyle üretilmektedir.

Kullanıldığı yerlere göre sınıflandırılan el dokumaSı halılar içinde yer alan yastık halılar yazılı kaynaklarda; "50x100 cm. boyutlarında altı adedi bir takım halinde dokunur. Sedir ve divanlardaki yastıkların ön yüzlerini süslerler.(Aytaç,1982). olarak tanımlanmaktadır.

Malatya il merkezinde bulunan müze, ev ve koleksiyonerler ile turistik mekanlarda ulaşılabilinen halı yastıklar arasından seçilen dokuz adet halı yastık üzerinde yapılan inceleme ve değerlendirme ile araştırma metni oluşturulmuştur.

\section{Yöntem}

Araştırma nitel verilere dayanmaktadır. Verilerinin elde edilmesinde öncelikle ilgili yayınlar tespit edilmeye çalışılmıştır. Görsel verilerini; araştırmacının seminer çalışmasından ve Malatya il merkezindeki müze, ev, koleksiyonerler ve turistik mekanlarda bulunan yastık halı örneklerinin gözlem ve incelemelerinden elde edilen kayıtlarından oluşturmaktadır. Ya- zılı ve görsel kaynaklar ile sözlü mülakatlardan elde edilen bilgilerin analizinden çıkan sonuçlar metne aktarılmaya çalışılmıştır.

\section{Malatya Yastık Halıları}

Yastık halılar; yerde oturma düzeninin bir parçası olarak duvara dayanan, içleri dolgulu sırt dayanaklarıdır. Malatya evlerinde kullanılmaya devam etmektedir. Yer sergisi halıların üzerinde, duvara dayatılarak kullanıldığı gibi bölgede divan olarak adlandırılan ahşaptan yapılmış, alt kısmı dolap olarak kullanılan oturma düzeneklerinde kullanılmaktadır. Sözlü kaynakların ifadelerinden edinilen bilgiye göre; geçmişte, karasal iklimin sert geçen kışlara sebep olmasından dolayı, yörede halı dokumalar içinde yer alan yastık halıların dokunmasını ve kullanılmasını zorunlu hale getirmiştir. Günümüzde geleneksel kültürün yaşatılmaya çalışılması sonucunda turistik alanlarda ve çeşitli ticari işletmelerde halı yastıklarla döşenmiş mekanlara sıkça rastlanılmaktadır.

\subsection{Teknik ve desen özellikleri}

Yastık halılar bölgede sarma ve germe(dik ve yatay) tezgâhlarda Gördes düğümü atılarak dokunmaktadır. Büyük ebatlı halılar için hazırlanan çözgü ölçülerine ekleme yapılarak dokunabildiği gibi genellikle germe ahşap tezgâhta arka arkaya iki veya üç adet olarak da dokunmaktadır. Halılarda geçmişte tamamen yün kullanılarak çözgü, atkı, ve ilmelik ipler hazırlanmaktayken, günümüzde büyük ölçüde çözgü ve atkı pamuk, ilmelik ipler yünden dokumaya devam etmektedir. Yörede küçük baş hayvancılığın azalması yün kullanımını etkilediği gibi çözgüde pamuk ipinin kullanılması, halı dokuma hatalarını aza indirmiştir. Yastık halılarda; çift veya üç atkı atılarak dokumalar yapılmaktadır.

Yastık halıların ölçümlerinde, eni 40 ile $70 \mathrm{~cm}$. arasında, boy ise; 75 ile $160 \mathrm{~cm}$. arasında değişmektedir. Halı yastıklardaki düğüm sayısı; $10 \mathrm{~cm}^{2}$ de: $18 \times 22$, 20x22 ile 24x26 arasında değişmektedir. Genellikle ilmelerdeki hav yüksekliği $0,5 \mathrm{~cm}$. ile $1,5 \mathrm{~cm}$. arasındadır. Yastık halıların, arka yüzeyine desensiz kilim dokuma yapılarak, kenarlarından elde dikişle tutturulur. Bazı yastık halılarda bu dikişin üzeri, ilmelik iplerden hazırlanan saç örgüsü şeklinde örülmüş veya büküm verilmiş iplerle kapatılarak ve köşelerde püskül bırakılarak süslenmektedir. Bazı yastık halılarda ise, bu iplerden kolçak denilen tutma yerleri dikilmeden bırakılmaktadır. Yastıkları taşımada ve yerlerini değiştirmede kolçak kolaylık sağlamaktadır. Yastık halıların kalitesinde, atkı sayılarının her sırada ikili veya üçlü olarak atılmasından kaynaklanan farklılıklar 
Songül ARAL

görülmektedir. Orta ve kalın kalite halı grubuna ait örnekler çoğunluktadır.

Yastık halılar, büyük ebatta dokunan halılarda yer alan desen, renk ve motif özellikleri ile benzer özellikler taşımaktadır. Eski tarihli yastık halı örneklerinde desenler; çiçekli, kuşlu, göl, aynalı, göbekli, anahtarlı gibi isimlerle adlandırılmaktadır. Büyük ebatlı halılarda dokunan ortada bulunan göbek deseni yastık halılarda da görülmektedir. Göbekli desenler genellikle göl olarak tanımlanmaktadır. Geometrik sınırlar içinde, motif olarak çoğunlukla koçboynuzu, canavar izi ve stilize çiçeklerin, kullanıldığı görülmektedir. Büyük ebatlı halıların dokunmasından sonra aynı renk ve desenle dokunan iki adet yastık halıdan oluşturulan üç adet halı ve kilim dokuma grubuna, yörede "çifti" denilmektedir

Yastık halılar, giderek azalan kökboyama kullanımı yanında sentetik boyalarla renklendirilmiş yün ipliklerle dokunmaktadır. Yastık dokumaların desenlerinde genellikle kullanılan renkler; zeminde ve motiflerde iç dolgusu olarak; bordo, lacivert, siyah ve gridir. Bu renkler bordodan açık kırmızıya doğru, lacivertten açık maviye doğru, siyahtan griye doğru farklı tonları ile kullanılmaktadır. Diğer renkler yeşil ve tonları, sarıya yakın turuncu ve tonları, krem, beyaz ve kahverengidir. 3.2 Katalog

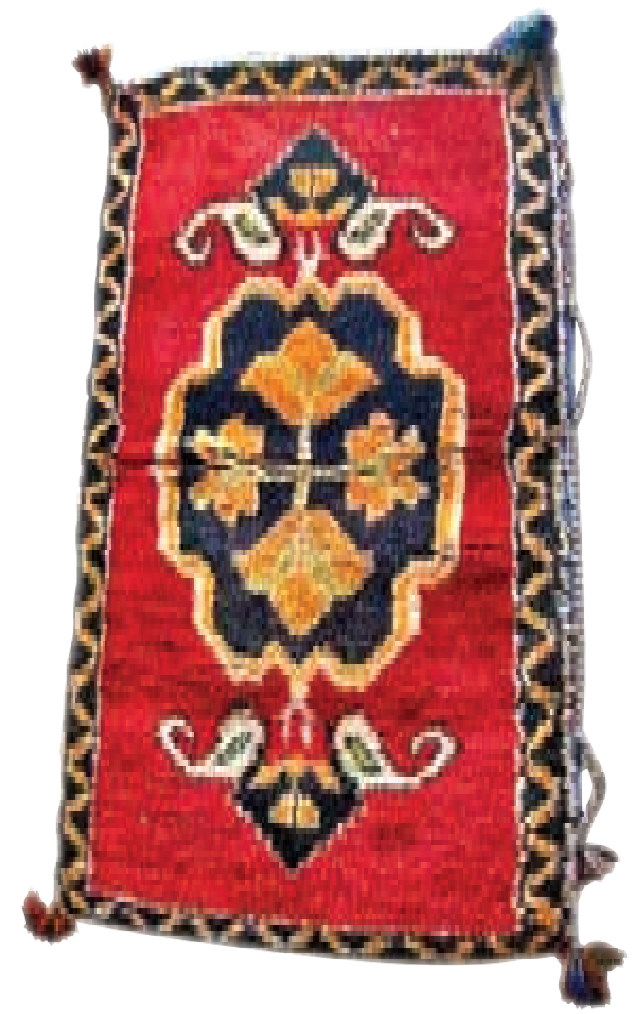

Örnek No / Fotoğraf No :1 "Çiçekli"desenli yastık halı.

İnceleme Tarihi $\quad: 16.09 .2010$

Tarihlendirme : 20.yüzyıl

\section{Cinsi : Yastık Halı \\ Yöresi : Malatya \\ Ebatlar1 $\quad: 60 \times 100 \mathrm{~cm}$ \\ Kalitesi : $26 \times 36$}

Kullanılan Malzeme : Çözgü; yün. Atkı; yün. İlmelik; yün. Seçilen Konu : : Geometrik, stilize bitki ve stilize hayvan desenleri

Boya Özelliği : Doğal ve kimyasal boyama.

Durumu : Kullanılabilir.

Kompozisyon : Yastık halı simetrik desenle dokunmuştur. Arka yüzey düz kilim dokumadır, doğal renkte bej ve kahverengi yün iplikler kullanılmıştır. Halı arka yüzeyinde ki desensiz kilim dokuma yüzeyler birleştirildikten sonra kenarlar saç örgülü iplerle kapatılmıştır. Bu iplerden üst kısımda bolluk bırakılarak "kolçak" denilen tutma yerleri yapılmıştır. Her köşede bu iplerden süsleme amaçlı püskül tutturulmuştur. Halı dokuma yüzeyinde; bordo zemin üzerine, ters simetrik stilize lale,çiçek, gonca ve yapraklardan oluşan bitkisel desen uygulanmıştır. Kıvrımlı orta desen konturu ve içinde yer alan laleler sarı, bej ve açık yeşil rente, zemini ise siyah renkte dokunmuştur. İnce tekli bordürde, su yolu deseni dokunmuştur.

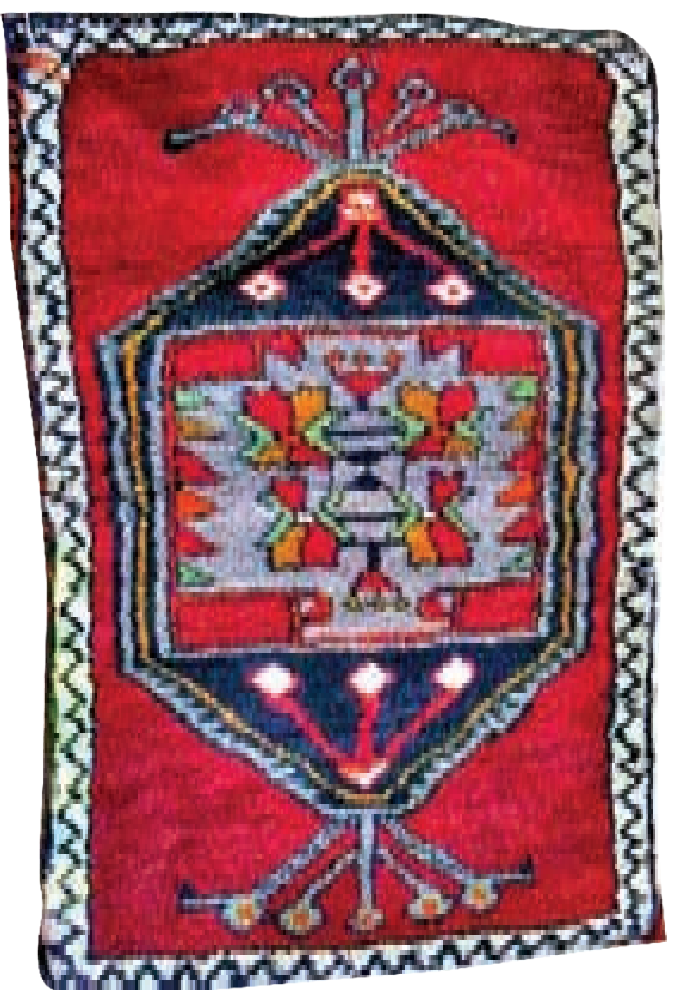

Örnek No/ Fotoğraf No :2 "Kuşlu" desenli yastık halı.

İnceleme Tarihi $\quad: 16.09 .2010$

Tarihlendirme : 20.yüzyıl

Cinsi : Yastık Halı

Yöresi : Malatya

Ebatlar1 $\quad: 65 \times 100 \mathrm{~cm}$. 
Kalitesi

$45 \times 44$

Kullanılan Malzeme : Çözgü; pamuk. Atkı; yün. İlmelik; yün.

Seçilen Konu Geometrik, stilize bitki ve stilize hayvan desenleri

Boya Özelliği

Durumu

Doğal ve kimyasal boya.

Kompozisyon

Kullanilabilir.

kunmuştur. Arka yüzey düz kilim dokumadır, kilim ve halı dokuma yüzeyler elde dikilerek birleştirilmiştir. Yastık halının başlama ve bitiş bölümünde yer alan kilim dokumalar başlarken 2cm.kırmızı ip ile, biterken $7 \mathrm{~cm}$.açık mavi ve koyu lacivert çizgili olarak dokunmuştur. Halı dokuma yüzeyinde, ince su açık mavi zemin üzerine lacivert renkte suyolu deseni dokunmuştur. Zemin bordo renk üzerine, dokuyucunun çiçek olarak tanımladığı stilize dört yapraklı motif, mavi, beyaz, turuncu, açık kahve, lacivert renkler kullanılarak desenlenmiştir. Çiçeğin her iki tarafında stilize karşılıklı duran kuş motifi dokunmuştur. Dokuyucunun, "gül dalına konmuş bülbüller" olarak ifade ettiği desenleme yapılırken ortada gül goncası tasvir edilmiştir. Köşelere süsleme amaçlı düğmeler dikilmiştir.

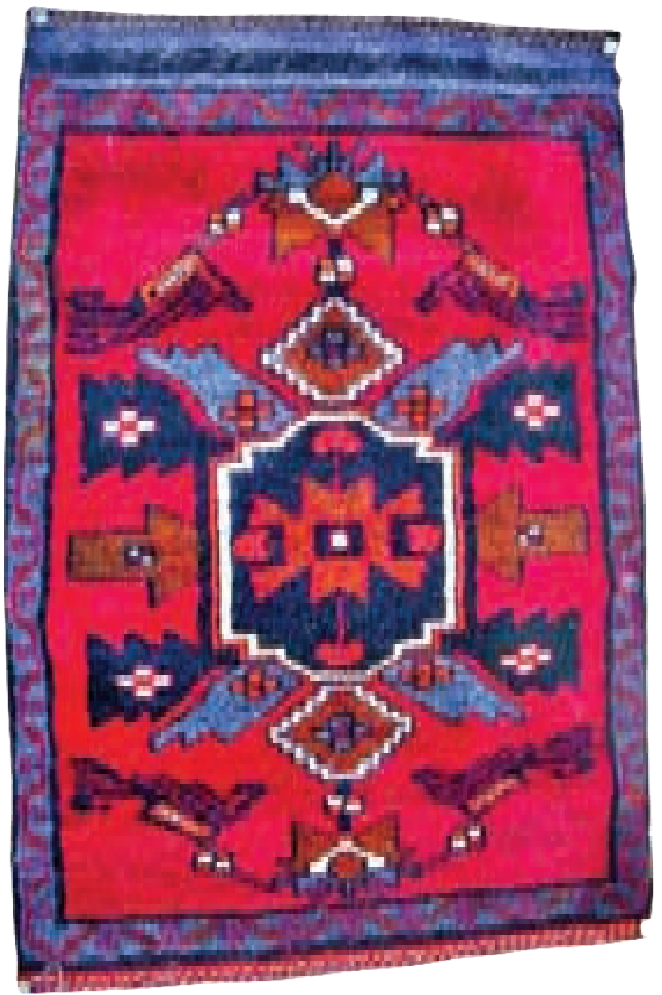

Örnek No/ Fotoğraf No : 3 "Göl" desenli yastık halı.

İnceleme Tarihi : : 16.09.2010

Tarihlendirme : 20.yüzyıl

Cinsi : Yastık Halı

Yöresi : : Malatya

Ebatlar1 : $65 \times 96 \mathrm{~cm}$

Kalitesi : $31 \times 35$
Kullanılan Malzeme: Çözgü; yün. Atkı; yün. İlmelik; yün. Seçilen Konu : : Geometrik, stilize bitki desenleri Boya Özelliği : Doğal ve kimyasal boya.

\section{Durumu} Kullanılabilir

Kompozisyon : Yastık halı simetrik desenle dokunmuştur. Arka yüzey beyaz, lacivert ve turuncu renklerde düz kilim dokumadır. Kilim ve halı dokuma yüzeyler birleştirildikten sonra kenarlar saç örgülü iplerle kapatılmıştır. Halı dokuma yüzeyinde, ince bordür beyaz zemine, siyah renkte su yolu deseni olarak dokunmuştur. Zemin bordo renk üzerine, gri, siyah, hardal sarı, turuncu, beyaz ve açık yeşilden oluşan geometrik madalyon deseni dokunmuştur. Sekizgen madalyon içinde kare görünümlü bir çerçeve, bu çerçeve içine geometrik birbirinin tekrarı içi dolgulu hatlar dokunmuş, gri zemin üzerine stilize yaprak, çiçek ve küpe motifleri yerleştirilmiştir.

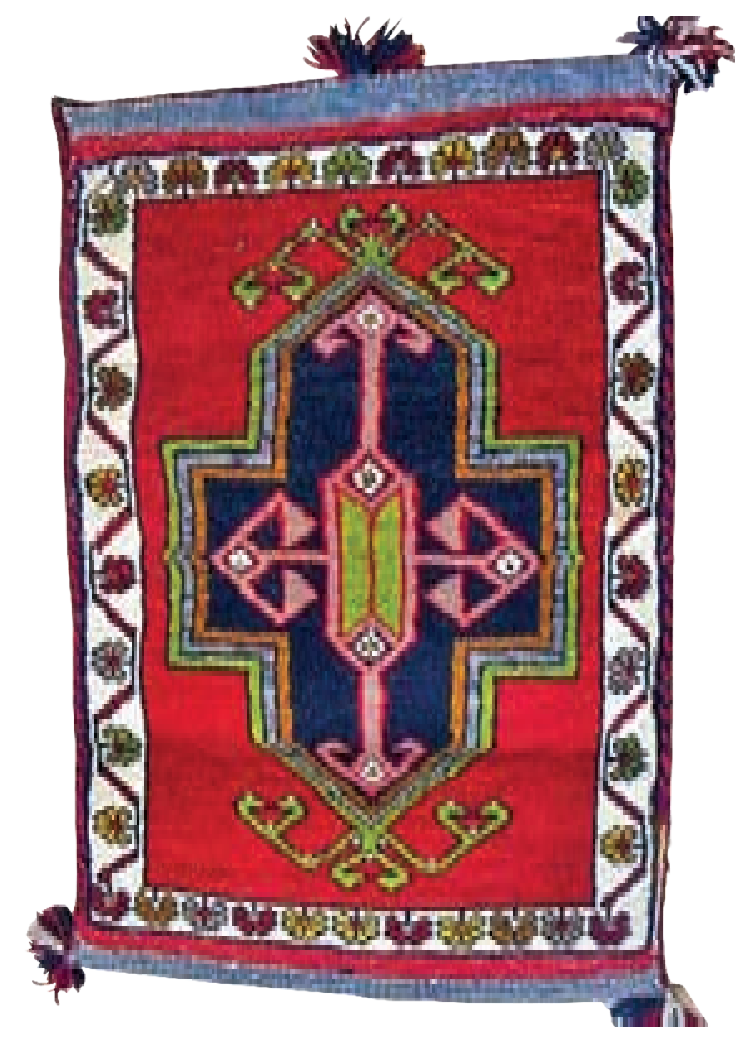

Örnek No/ Fotoğraf No : 4 "Aynalı" desenli yastık halı.

İnceleme Tarihi : : 16.09.2010

Tarihlendirme : 20.yüzyıl

Cinsi : Yastık halı

Yöresi : Malatya

Ebatlar1 : $50 \times 75 \mathrm{~cm}$.

Kalitesi : $27 \times 37$

Kullanılan Malzeme : Çözgü; pamuk. Atkı; yün. İlmelik; yün. Seçilen Konu : Geometrik, stilize bitki desenleri. Boya Özelliği : : Doğal ve kimyasal boya.

Durumu : Kullanilabilir. 
Songül ARAL

Kompozisyon : Yastık halı simetrik desenle dokunmuştur. Arka yüzey beyaz renkli düz kilim dokumadır. Kilim ve halı dokuma yüzeyler birleştirildikten sonra lacivert ve bordo renkli ipler büküm verilerek iki uzun kenara dikilmiştir. Püsküller süsleme amaçlı köşelerde kullanılmıştır. Halı dokuma yüzeyinde, ince bordür beyaz zemine, stilize küçük çiçekler dokunmuştur. Bu çiçekler iki uzun kenarda, verev çizgiler zigzag deseni verilerek içlerine sıralamıştır. Kısa kenarlarda ise yan yana dokunmuştur. Zeminde bordo renk üzerine, yeşil, gri, hardal sarısı renklerde konturların sınırlandırdığı, geometrik göbek desenlenmiştir. Madalyonun iki sivri uçlu kenarına ters simetrik olarak ve dokuyucunun çengel olarak adlandırdığı motifler yerleştirilmiştir. Konturların içte kalan zemini siyah renkli zemin dokuma içine bordo konturlu, gri renk dolgulu eli belinde desenleri karş1lıklı yarım motif olarak dokunmuştur. Orta kısımdaki yeşil renkte geometrik motifin ve koçboynuzu motiflerinin ortalarına göz motifi dokunmuştur.

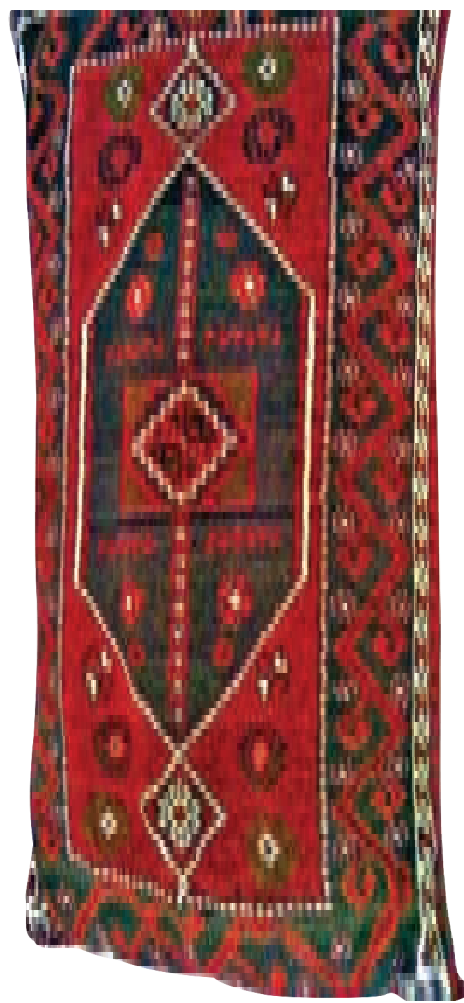

Örnek No/ Fotoğraf No : 5 "Göbekli" desenli yastık halı.

$\begin{array}{ll}\text { İnceleme Tarihi } & : 19.09 .2010 \\ \text { Tarihlendirme } & : 20 . y u ̈ z y 1 l \\ \text { Cinsi } & \text { : Yastık halısı } \\ \text { Yöresi } & \text { : Malatya } \\ \text { Ebatları } & : 50 \times 122 \mathrm{~cm} \\ \text { Kalitesi } & : 26 \times 35\end{array}$

Kullanılan Malzeme: Çözgü; yün. Atkı; yün. İlmelik; yün Seçilen Konu : : Geometrik ve stilize bitki desenleri.

\section{Boya Özelliği : Doğal ve kimyasal boya Durumu : Kullanilabilir.}

Kompozisyon : Yastık halı simetrik desenle dokunmuştur. Arka yüzey kilim dokumadır. Bordür orta zemine oranla enli dokunmuştur. Kenar küçük su birbirine bağlı sıralı ve içleri dolgulu geometrik desenlidir. Büyük su $20 \mathrm{~cm}$. eninde aralarına serpiştirilmiş stilize çiçek motifleri yerleştirilmiş bağlantılı çengel motifi olarak dokunmuştur. İç kısımda ince su çerçeve, beyaz renkte dikdörtgen formlu ve iki atlamalı olarak dokunmuştur. Orta zemin bordo renkte ve ortada geometrik altıgen büyük göbek iki ucunda dörtgen formu içine akrep motifi dokunmuştur. Göbek deseninin içi siyah renkte olup bir merkeze doğru desenlenmiş geometrik ve stilize çiçek motifleri ile desenlenmiştir. Sahibinden alınan bilgiye göre Babaannesi tarafından 1918 yılında dokunmuştur.

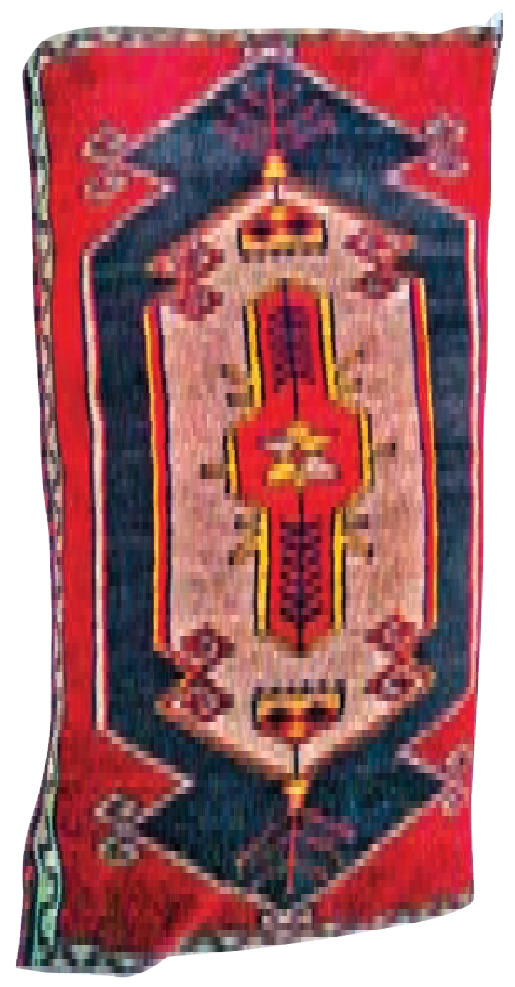

Örnek No/ Fotoğraf No : 6 "Anahtarlı" desenli yastık halı

İnceleme Tarihi $\quad: 19.09 .2010$

Tarihlendirme : 20.yüzyıl

Cinsi : Yastık halısı

Yöresi : Malatya

Ebatlar1 $\quad: 63 \times 119 \mathrm{~cm}$.

Kalitesi : $31 \times 37$

Kullanılan Malzeme: Çözgü; pamuk. Atkı; pamuk. Ilmelik; yün Seçilen Konu : : Geometrik, stilize bitki desenleri Boya Özelliği : Doğal ve kimyasal boya Durumu : Kullanılabilir. 
Kompozisyon : Yastık halı simetrik desenle dokunmuştur. Arka yüzey kilim dokumadır. Bordür tek küçük su, içinde birbirine bağlantılı suyolu motifi bulunan gri renkte dokunmuştur. Orta zemin, altıgen formunda, kenarları koçboynuzu motifleri ile gri renkte dokunmuştur. Zemin içine aynı formda ancak içbükey koçboynuzu süslemesi ile sarı, kırmızı, lacivert sınırlar dokunmuş, iki sivri uçta birbirinin aynı, kırmızı renkte stilize ağaç dalı olan ikinci bir altıgen formlu göbek dokunmuştur. Böylece içiçe iki göbek formu içinde karşılıklı iki küpe motifi ve tam ortada geometrik sarı kırmızı renkte ve ortasında stilize çiçek ve buna bağlı stilize yaprak deseni bulunmaktadır. Ortada birbirine bağlantılı geometrik bezeme simetrik olarak, alt ve üstünde ise dikdörtgen formlu içi renkli küçük dolgulu karelerle bezenmiş şeritlerle desenlenmiştir. Göbeklerin dış köşeleri üçgen şeklinde siyah renkli zemin içine serpiştirilmiş birbirinin benzeri stilize çiçek motifleriyle desenlenmiştir.

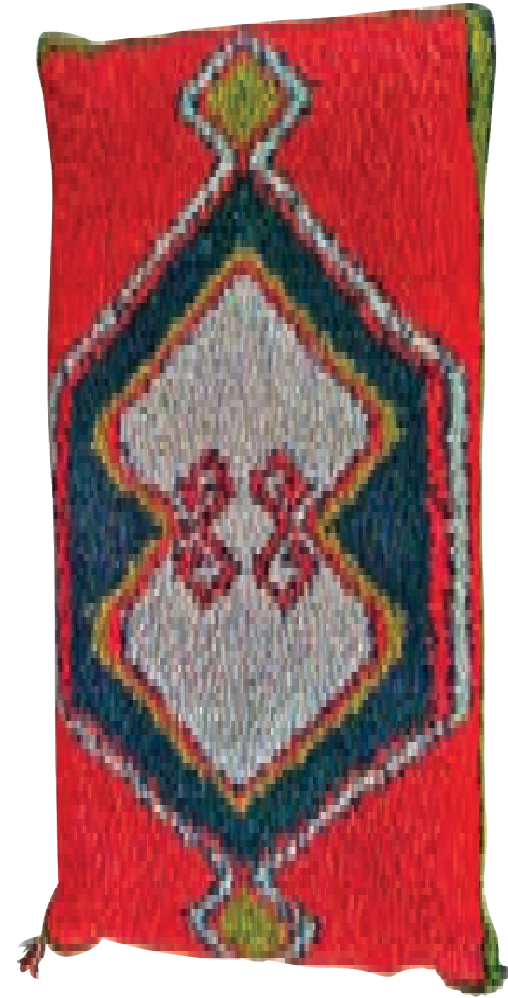

Örnek No/ Fotoğraf No : 7 "Aynalı" desenli yastık halı.

$\begin{array}{ll}\text { İnceleme Tarihi } & : 19.09 .2010 \\ \text { Tarihlendirme } & : 20 . \text { yüzyll } \\ \text { Cinsi } & : \text { Yastık halısı } \\ \text { Yöresi } & : \text { Malatya } \\ \text { Ebatları } & : 50 \times 110 \mathrm{~cm} . \\ \text { Kalitesi } & : 26 \times 32\end{array}$

Kullanılan Malzeme: Çözgü; pamuk Atkı;pamuk İlmelik; yün Seçilen Konu : : Geometrik, stilize hayvan desenleri Boya Özelliği : Doğal ve kimyasal boya

\section{Durumu : Kullanılabilir.}

Kompozisyon : Yastık halı simetrik desenle dokunmuştur. Arka yüzey kilim dokumadır. Bordür tek küçük su olarak sınırları siyah içi yeşil renkte dokunmuştur. Bordo renkli zemin içine altıgen formlu göbek desenlenmiştir. Göbek içinde birbirine bağlantılı baklava dilimi şeklinde desen; gri, bordo siyah ve yeşil renkler kullanılarak dokunmuştur. İçte karşılıklı, bordo renkte ters simetrik koçboynuzu motifi yer almaktadir.

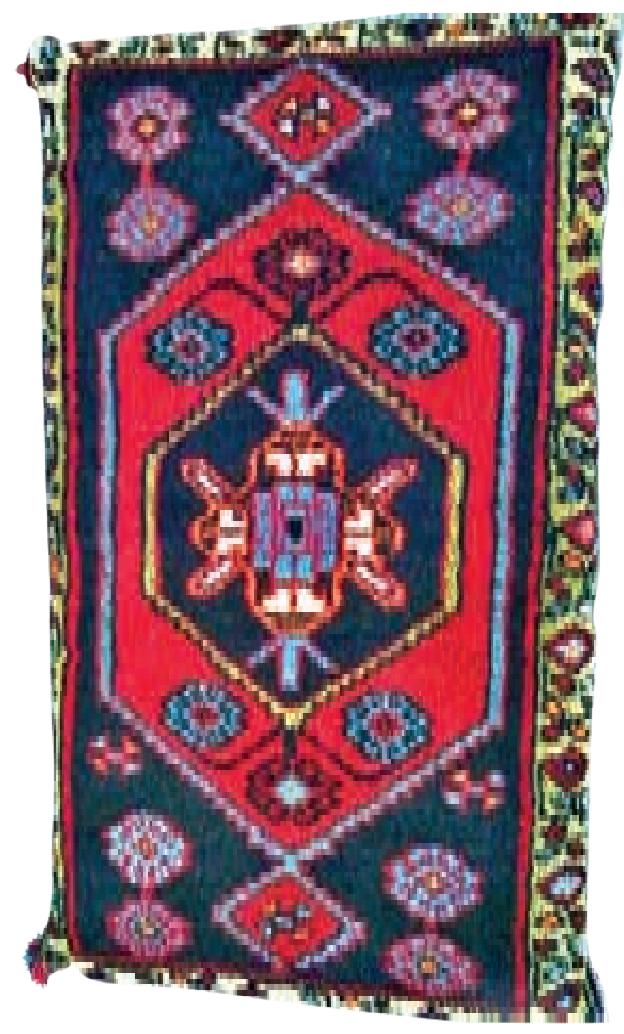

Örnek No/ Fotoğraf No : 8 "Göl” desenli yastık halı.

İnceleme Tarihi $\quad: 19.09 .2010$

Tarihlendirme : 20.yüzyıl

Cinsi : Yastık halısı

Yöresi : Malatya

Ebatları : $70 \times 116 \mathrm{~cm}$.

Kalitesi : 32x35

Kullanılan Malzeme: Çözgü; pamuk Atkı; yün İlmelik; yün Seçilen Konu : : Geometrik, stilize bitki desenleri Boya Özelliği : Doğal ve kimyasal boya Durumu : Kullanılabilir.

Kompozisyon : Yastık halı simetrik desenle dokunmuştur. Arka yüzey, bordo siyah renklerde çizgili kilim dokumadır. Kilim ve halı dokuma yüzeyler dikilerek birleştirilmiş, dikişlerin üzeri saç örgüsü örülmüş ipliklerle kapatılmıştır. Her köşede bu ipliklerden süsleme amaçlı püskül tutturulmuştur. Halı dokuma yüzeyi stilize bitkisel, birbirinin tekrarı çiçek, yaprak ve dallardan oluşan desenlerle bezenmiş bordür 
Songül ARAL

ile çerçevelenmiştir. Hardal sarısı zemin üzerine bordo, turuncu, mavi, siyah renkler kullanılmıştır. Bordürden sonra zemin siyah renkte üzerinde mavi, bordo sarı renklerde karşılıklı yerleştirilmiş akrep ve kurtağzı motifleriyle bezenmiştir. Ortada altıgen formlu bir göbek desenlenmiştir. Bordo zeminli göbek ortasında altıgen formlu diğer bir desen iki ucunda karşılıklı duran akrep motifleriyle bezenmiştir. Ortada dokuyucunun göl olarak adlandırdığı geometrik büyük motif yer almaktadır.

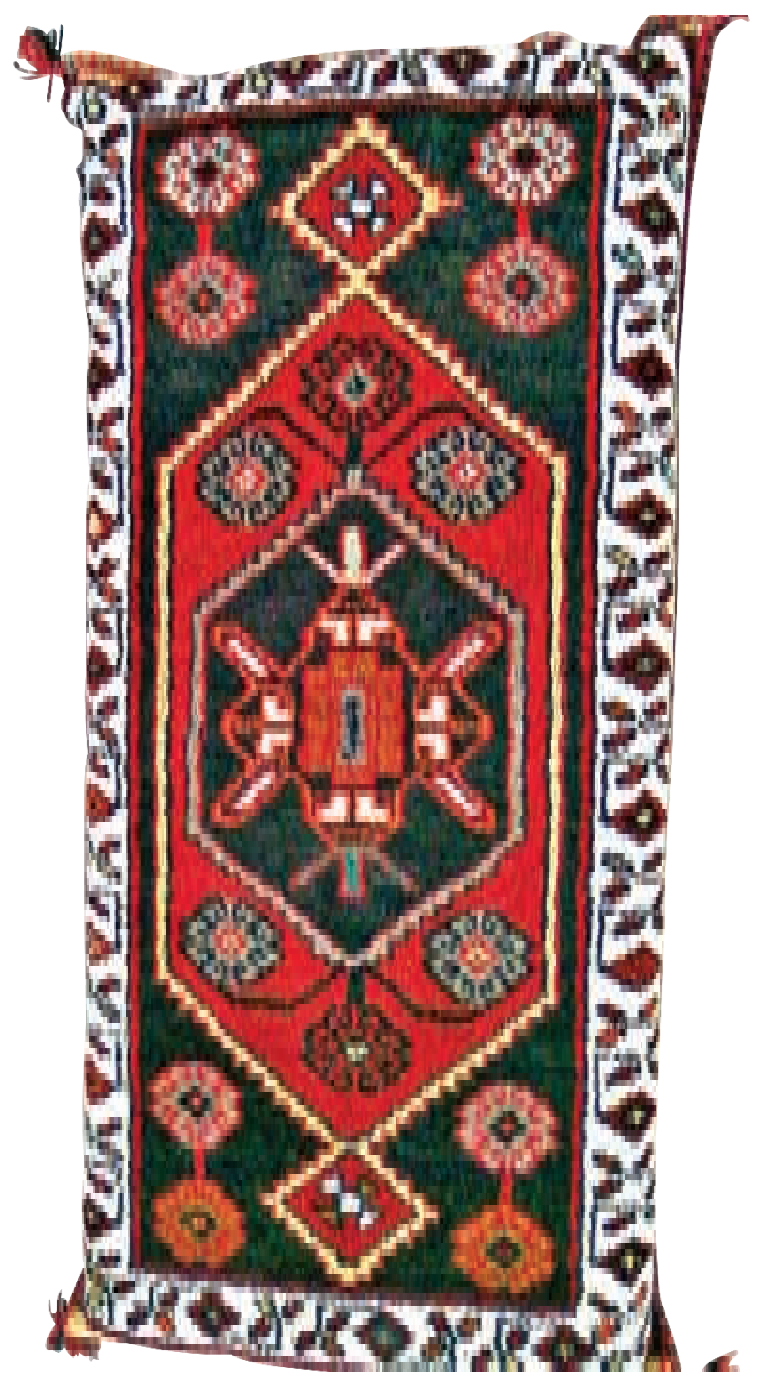

Örnek No/ Fotoğraf No : 9 "Göl" desenli yastık halı.

İnceleme Tarihi $\quad$ : 19.09.2010

Tarihlendirme : 20.yüzyıl

Cinsi : Yastık halısı

Yöresi : : Malatya

Ebatları : $60 \times 160 \mathrm{~cm}$.

Kalitesi : 29x34

Kullanılan Malzeme : Çözgü; pamuk Atkı; pamuk Illmelik; yün Seçilen Konu : : Geometrik, stilize bitki desenleri Boya Özelliği : Doğal ve kimyasal boyama Durumu : Kullanilabilir.
Kompozisyon : Yastık halı simetrik desenle dokunmuştur. Arka yüzey çizgili kilim dokumadır. Kilim ve halı dokuma yüzeyler dikilerek birleştirilmiş, dikişlerin üzeri saç örgüsü örülmüş ipliklerle kapatılmıştır. Her köşede bu ipliklerden süsleme amaçlı püskül tutturulmuştur. Halı dokuma yüzeyinin kenarı bordo renkte iki çizgiden oluşan küçük su ile arasında birbirinin tekrarı stilize çiçek, dal ve yaprak bunlarında aralarında baklava dilimi şeklinde dörtgen formlardan desenlenmiş büyük su ile bordür dokunmuştur. Bordürden sonra zemin siyah renkte üzerinde gri, açık mavi, turuncu renklerde karşılıklı yerleştirilmiş akrep ve kurtağzı motifleriyle bezenmiştir. Ortada altıgen formlu bir göbekle desenlenmiştir. Bordo zeminli göbek ortasında altıgen formlu diğer bir desen iki ucunda karşılıklı duran üçer adet akrep motifleriyle bezenmiştir. Ortada dokuyucunun göl olarak adlandırıldığı geometrik büyük motif yer almaktadır.

\section{Değerlendirme ve Sonuç}

Günümüzde sürdürülebilinen el sanatları arasında yer alan Malatya halı dokumalarından olan yastık halılar, değişen beğeni ve istek doğrultusunda yörede kadınların kendi evlerinde ve halk eğitim merkezi kurslarında üretimini yapabildikleri dokumalardandir.

Malatya halı dokuma grubunun küçük ebatlı örnekleri olarak tanımlanabilecek yastık halıların, yazılı kaynaklarda yeterince yer almaması sebebiyle yapılan araştırmada teknik özellikleriyle ilgili sonuçlara ulaşılmıştır. Yastık halılarının teknik özelliklerini genel olarak sıralamak araştırma sonucunda mümkün olmaktadır. Desenler çoğunlukla 4/1 olarak dokunmuştur. Bu çalışmayla görülen ve incelenen geçmiş tarihli yastık halı örnekleri ile günümüz dokumalarına yansıyan motif ve desenler benzer özellikler taşımaktadır. Geçmişte kullanılan atkı ile çözgü iplerinin çoğunlukla yün, günümüzde ise çözgü ve atkının çoğunlukla pamuk, ilmelerin ise yün iplik olduğu tespit edilmiştir.

Geçmişte dokuma ipleri kök boyama ile günümüzde ise çoğunlukla sentetik boya kullanılmasıyla renklendirilmiştir. İlmelerdeki hav yüksekliği 1 ile $1,5 \mathrm{~cm}$.arasında değişmektedir. Halı sanayine giren halılar traşlanarak hav yüksekliği istenilen boyuta indirilmektedir. Ayrıca yastık halılarda dolgu malzemesi olarak kırpıntı olarak adlandırılan ilme kesiminden artan yünler kullanılmaktadır. Bazı yastıklarda sünger kullanılmıştır. Arka yüzeyler çoğunlukla kilim 
dokumadır. Bazı örnekler ise kalın kumaşla kaplanmiştır. Genellikle bordürler tek su olarak dokunmuştur, zeminde ortada bir göbekli ve etrafında geometrik, sembolize ve stilize bitkisel motiflerin yer aldı $\breve{g ̆}_{1}$ desenlemeler bulunmaktadir.

Daha önceki araştırmalardan "pişinik"1 olarak tanımlanan, yastık halı örnekleri ile benzer özellikler bulunmaktadır. Bu yastık halıların belirgin özelliği kenar sularının geniş desenli olmasıdır. Göbek desenli orta zeminleri ve motifleri ile kilim dokumalarındaki genişlikleri Malatya yastık halıları ile ortak görünümdedir. Pişinik halılarıyla ilgili bir örnek de araştırma kapsamında yer almaktadır

Malatya yastık halıları, büyük ebatlı halılar için hazırlanan çözgü ölçülerine ekleme yapılarak tezgaha aktarılmaktadır. Dokumalar sarma tezgahlarda yapılabildiği gibi, genellikle germe ahşap tezgahta arka arkaya iki veya üç adet olarak da dokunmaktadır. Malatya kirkitli dokumalarında görülen geometrik motifler yastık halılarda da kendini göstermektedir. Seccade ve divan halılarında kullanılan bitkisel motifler yastık halılarında kenar suyu olarak karşımıza çıkmaktadır. Yastık halılardaki saçak ile kilim dokumanın üzerine, yünden yapılmış püsküller ile nazara karşı boncuk ve düğmelerin süsleme amaçlı olarak dikildiği görülmektedir.

Yastık halılarda kaliteyi belirleyen ilme sayıla-

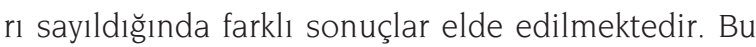
farklılıklar atılan atkı sayısının dokumanın bazı yerlerde iki bazı yerlerde üç sıra olarak değişmesinden kaynaklanmaktadır.

Malatya yastık halıları, yaşam alanlarındaki rahat kullanım özelliği ile üretimi devam eden halı gurubudur. Büyük ebatlı halılara göre üretimi daha hızlı ve az malzeme kullanılarak kısa zamanda tamamlanmaktadır. Yastık halıların, dekorasyon ve ilgili alanlarında kullanımı yaygınlaştırılabilir. Üretimine destek verilmesi ile de sürekliliği sağlanabilir bir dokuma grubudur. Geçmişe ait mevcut örneklerin tespiti, kayıt altına alınması öneriler arasındadır.

\section{Kaynaklar}

Aral, Songül (2008), "El Dokuması Halı Üretimi Yapan Atölyelerde Çalışma Ortamlarından Kaynaklanan Sorunlar", 14. Ulusal Ergonomi Kongresi, KATÜ Bildiriler Kitabı Cilt I, Trabzon: KATU Yayınları.

Aytaç, Çetin (1982), El Dokumacılı̆̆ı, Ankara: Milli Eğitim Bakanlığı Yayınları.

Aytaç, Ahmet (2010), "Türk Dokuma Sanatında Konya Yöresine Ait Halı Yastıklar ve Bir Koleksiyon", IV.Uluslararası Türk Kültürü ile Sanatları Kongresi/Sanat Etkinlikleri, Kahire/Sharm El Sheikh-Mısır, Konya.

Erbek, Güran (1985), Anatolian Motifs, German,

Malatya Valiliği (1992), Malatya Motifi. Ankara: Vakıfbank Yayınları.

Dengiz, Makbule, Erdoğan, Zeynep (2008), “Pişinik Yastık Halısı" 38.Icanas (Uluslararası Asya ve Kuzey Afrika Çalısmaları Kongresi) Maddi Kültür, Ankara.

1 Makbule Dengiz - Zeynep Erdoğan, "Pişinik Yastık Halısı". 38 Icanas (Uluslararası Asya ve Kuzey Afrika Çalışmaları Kongresi) Maddi Kültür, Ankara, 2008 